\title{
Viewpoint: The Need for Qualitative Research to Understand Ranch Management
}

\author{
Nathan F. Sayre \\ Department of Geography, 507 McCone Hall \#4740, University of California, Berkeley CA, 94720-4740
}

\begin{abstract}
The use and management of rangelands involves both ecological and social processes, and it is in the interaction of these that conservation is or is not achieved. Overall, the ecological dimensions of rangelands and rangeland management have been studied in greater detail and are better understood than the social dimensions. This paper argues that qualitative methods are necessary to understand the management of rangelands by ranchers. Existing studies using quantitative methods have found little correlation between ranchers' management practices and a variety of social factors. One consistent finding of these studies, however, is that profit is a secondary or insignificant motivation among ranchers, casting doubt on the premise that economic self-interest motivates ranchers to embrace improved management practices. The theoretical and methodological implications of this finding have not been adequately recognized in rangeland science. With its greater flexibility and attention to context, qualitative research can reveal social, historical, political, and economic factors that affect ranch management but have eluded quantitative studies. In addition, qualitative methods are better suited to capturing both the processes that generate ranchers' "mental models" and the historical information needed in light of recent theoretical advances in rangeland ecology. Suggestions for future research on ranch management include conducting case studies of smaller areas over longer temporal periods, focusing on interactions among ranchers, giving ranchers a greater role in identifying research needs, studying urbanization and other "new" rangeland issues, and drawing on research about pastoralist societies elsewhere.
\end{abstract}

\section{Resumen}

El uso y manejo de los pastizales involucra tanto procesos ecológicos como sociales y es en la interacción de estos que la conservación se logra o no. En general, las dimensiones ecológicas de los pastizales y del manejo de ellos han sido estudiadas en mayor detalle y son mejor entendidas que las dimensiones sociales. Este articulo discute que métodos cualitativos son necesarios para entender el manejo de los pastizales que realizan los rancheros. Los estudios existentes que han usado métodos cuantitativos han encontrado poca correlación entre las prácticas de manejo de los rancheros y una variedad de factores sociales. Un hallazgo consistente de estos estudios es que las ganancias son una motivación secundaria o insignificante entre los rancheros, causando duda sobre la premisa de que el interés económico motiva a los rancheros a incluir prácticas de mejoramiento de pastizales. Las implicaciones teóricas y metodológicas de este hallazgo no han sido reconocidas adecuadamente en la ciencia de pastizales. Con esta gran flexibilidad y atención al contexto la investigación cualitativa puede revelar factores sociales históricos, políticos y económicos que afectan el manejo del rancho pero que han sido eludidos en los estudios cuantitativos. Además, los métodos cualitativos son más apropiados para capturar tanto los procesos que generan los "modelos mentales" de los rancheros y la información histórica necesaria a raíz de los recientes avances teóricos de la ecología de pastizales. Las sugerencias para la investigación futura del manejo de pastizales incluyen: conducir estudios de caso en pequeñas áreas por periodos largos de tiempo; enfocarse en las interacciones entre los rancheros, dando a ellos un papel mayor en identificar las necesidades de investigación; estudiar la urbanización y otros "nuevos" problemas de los pastizales e inspirar la investigación sobre las sociedades pastoriles de otros lugares.

Key Words: land use change, qualitative research methods, mental models, ranchers, ranch management, social processes, sustainability

\section{Introduction}

The use and management of rangelands involves both ecological and social processes (Huntsinger and Hopkinson 1996). Whether a rangeland use is sustained depends not only on biophysical processes such as photosynthesis, water and mineral cycling, and competition but also on how economics, politics, and other social phenomena influence those processes. "The human processes are as important as the ecological

Correspondence: Nathan F. Sayre, 507 McCone Hall \#4740, University of California, Berkeley CA, 94720-4740. Email: nsayre@socrates.berkeley.edu

Manuscript received 24 April 2003; manuscript accepted 15 June 2004. processes" (Lynam and Stafford Smith 2003). If so, there is equal need to understand the social processes that determine rangeland use and management as there is to understand biophysical processes. Overall, however, the ecological dimensions of rangelands have received greater research emphasis and are better understood than the social dimensions.

A central premise of traditional programs in rangeland research and extension is that private producers will choose to apply best management practices out of enlightened selfinterest-that is, because they themselves stand to benefit economically from improved ecological conditions, at least in the long term. However, studies conducted over the past 4 decades consistently indicate that profit is not the primary motive of western ranchers, and that in many cases it is not 
even a secondary motive. Ranchers do not behave like idealized economic firms, and the social processes that lead to good management cannot be reduced to the standard calculus of monetary costs and benefits. How, then, should ranch management be studied? Alternative models of how land managers adopt technology have been developed to incorporate factors such as risk and uncertainty, community and demographic characteristics, and communication (Fliegel 1993; Zepada 1994). But the intangibility of some of these factors has made testing the models difficult (Kreuter et al 2001).

This paper argues that qualitative methods are needed to improve our understanding of rangeland management by ranchers. The first section critiques the quantitative methods employed in most studies of ranchers published in the rangeland science literature. This research has found little correlation between ranchers' management practices and either demographic characteristics or expressed value orientations. Curiously, moreover, these studies descend from research by agricultural economists who concluded that nonquantitative methods were necessary to understand ranchers' decision making. The second section presents 3 arguments for qualitative research. First, qualitative methods are capable of discovering factors that are unanticipated and thus undetectable using purely quantitative methods. Second, qualitative methods are better suited to the spatial and temporal scale of the key processes at issue: interactions between ranchers' "mental models" (Lynam and Stafford Smith 2003) and the biophysical landscapes they manage. Third, recent theoretical developments in rangeland ecology indicate a strong need for greater historical research, which will have to rely heavily on qualitative data. The final section suggests directions for further research to improve the relationship between rangeland science and ranch management in today's West.

\section{Limitations of Quantitative Methods}

Most studies of US ranchers published in range-oriented journals in the past 40 years rest on quantitative methods. Generally, researchers have employed survey instruments (usually questionnaires administered in person or by mail) to gather data from ranchers over a given area (usually one or more counties, a state, or in one case the entire West) and then subjected the resulting data to statistical analysis. Some studies have addressed management issues directly, others only obliquely. Often the main focus has been policy issues such as grazing fees, planning and zoning, or environmental regulations. Only a few dependable patterns have emerged from these studies regarding how ranchers make management decisions.

One such study, based on questionnaires mailed to 7000 ranchers in Texas (Hanselka et al 1990; Rowan and White 1994; Rowan et al 1994a, 1994b), revealed that off-ranch employment and investment were important income sources for ranchers throughout the state, larger ranches were less dependent on off-ranch income than smaller ranches, and ranchers located closer to urban centers tended to be less dependent on livestock for their livelihoods. Two correlations were observed between demographic characteristics and management decisions: more livestock-dependent ranchers were more likely to invest in weed and brush control, and ranchers practicing "decisional rotation" (unplanned rotation of multiple herds) were slightly more dependent on ranch income. But no other correlations were significant.

Methods of factor analysis and principal component analysis, intended to elicit "patterns of behavioral similarities" among ranchers, produced a model that explained only $2 \%$ of the variability in grazing program decisions. The factors that most strongly influenced decisions to change stocking ratesdrought and rainfall-were unrelated to ranchers' individual characteristics or backgrounds. The authors concluded that "a number of points about rancher decision-making are indistinct and should be studied further" (Rowan et al 1994b).

Another study (Liffmann et al 2000) used questionnaires from 245 ranchers in 3 counties in California: 2 experiencing rapid urban development and 1 not (the 2 urbanizing counties were grouped together for analysis). Significant differences were found between the 2 groups of ranchers in terms of education, income, dependence on ranch income, duration of tenure on the ranch, and size of private holdings. Ranchers in the rural county were more likely to hunt and fish on their ranches, and ranchers in the urbanizing counties were more likely to raise horses. The rural ranchers placed a greater emphasis on protecting scenic values and were more favorably disposed toward state cooperative extension programs. Numerous significant differences were found in management practices, but most appear to have reflected differences in the landscapes' natural features and ownership patterns rather than rancher propensities (eg, use of irrigation and commercial fertilizers, raising of sheep, fencing of riparian areas, installation of water developments, and use of continuous year-round or rotational grazing schemes). Overall, the 2 groups appeared basically similar in their goals and motivations, their propensity to implement various management practices, and their commitment to conservation. In and of itself, proximity to urban development did not strongly determine rangeland management practices.

Coppock and Birkenfeld (1999) utilized questionnaires from 340 randomly selected Utah ranchers with public land grazing permits to identify patterns in management practices, concerns, and coping strategies. They identified 3 socioeconomic variables-dependence on off-ranch income, dependence on family labor, and dependence on public land-which clustered ranchers into 5 groups (see the following discussion); group membership appeared to influence rates of use of 9 out of 26 management practices in the survey, including rest and deferred rotation and prescribed fire. (Four of the 9 concerned finance and marketing.) Higher income and education levels and larger scales of operation correlated with greater use of management practices overall. Other factors varied widely, however, and all groups showed "remarkably similar" concerns and coping strategies.

Later, Peterson and Coppock (2001) extended the study with 393 phone surveys: 192 with ranchers from the earlier study and 201 with randomly selected, private-land-only ranchers. The 2 groups were similar in average age, education, managerial experience, and community involvement, but permittees were more profit-oriented and less hobby-oriented than the private ranchers. This appeared to reflect the fact that permittees were also much larger-scale operators, controlling the vast majority of private grazing land, beef cattle, and sheep in Utah despite being slightly less numerous overall. Eighty percent of all Utah ranchers were described as "passive" managers, 39\% 
had impending plans to retire, and one-third planned to sell their ranches to real estate developers. These factors, along with low cattle prices, appeared to discourage active management among most ranchers. Conversely, active managers had higher incomes and greater willingness to assume debt, leading the authors to note that "wealth is a reliable predictor of innovative, risk-tolerant behavior."

Numerous studies have examined ranchers' values and motivations, again utilizing questionnaires to gather data from enough individuals to permit statistical manipulation of the results (Harper and Eastman 1980; Biswas et al 1984; Bartlett et al 1989; Young and Shumway 1991; Huntsinger and Hopkinson 1996; Liffmann et al 2000; Rowe et al 2001; Gentner and Tanaka 2002). These studies did not seek to explain management decisions and practices (and cannot be faulted for not doing so), but they are relevant here because they reveal the shortcomings of the premise noted previously: that improved management is economically motivated. The common theme of these studies' findings is that ranchers. (and farmers) are not rational in the strict economic sense of the term: they commonly absorb significant opportunity costs and tolerate suboptimal returns on investment because other values are more important to them than profit.

This body of research shares a common intellectual progenitor: an article by William Martin and Gene Jefferies published in the Journal of Farm Economics in 1966. Martin and Jefferies gathered data on 160 Arizona ranch sales that occurred between 1957 and 1963, and they asked why sales prices in their data set were so much higher than standard economic theory would predict. Rates of return on investment were consistently very low to negative; buying a ranch at market prices was economically irrational. The data indicated that distance to urbanized areas did not explain variation in sales prices and that lease rates for public and private rangelands were also irrationally high, so the authors concluded that neither simple real estate speculation nor tax shelter benefits could explain the sales data. Based on interviews with the buyers and sellers, Martin and Jefferies suggested 2 additional motivations: "ranch fundamentalism" and conspicuous consumption. In brief, ranch fundamentalism explained why longtime ranchers did not sell despite low returns and high opportunity costs; conspicuous consumption explained why ranch buyers paid such high prices when they could make more money by investing elsewhere.

Seeking to explain the difference between ranchers who were willing to sell and those who weren't, Martin later teamed with another graduate student, Arthur Smith, to extend the research using discriminant analysis (Smith and Martin 1972). They conducted interviews using questionnaires with 89 Arizona ranchers, from a random sample of all the ranchers in the state, and arrived at 11 factors that explained $69.2 \%$ of the variability in rancher responses to 33 questions. After further analysis, they reduced these to 3 significant factors: land fundamentalism, conspicuous consumption/speculative attitudes, and rural fundamentalism. The first 2 were basically the same as in the earlier article, with "ranch" changed to "land"; the last was a factor necessary to explain why some ranch fundamentalists nevertheless do sell their ranches. Eighty percent of the ranchers in this sample had "outside jobs or income to help support the ranch," and the authors speculated that the availability of such jobs locally may have had more to do with preserving ranching than ranching had to do with rural economic well-being. They also introduced the term "satisficing" to describe the mix of monetary and nonmonetary rewards that ranchers obtained from ranching.

Martin and his students did not attempt to explain tactical management decisions but rather strategic investment decisions-why ranchers continue to ranch when selling their land makes more economic sense. It is quite possible that, having made the (economically irrational) strategic decision to continue ranching, ranchers nevertheless evaluate tactical management decisions in an economically rational fashion. But testing this proposition is difficult because of the tremendous natural and social variability that characterizes western ranching. As Fowler and Gray (1988) somewhat famously put it,

In ranching, researchers are actually dealing with a double infinity. The first infinity deals with the vast numbers of range types, soils, slopes, aspects, climatic variables, and the whole array of physical variation that exists in the western ranchland areas. The second infinity arises from the institutional and social aspects of ranching families. Managerial ability, skill, and knowledge vary drastically from rancher to rancher. In addition, planning horizons differ; profit motivation is not necessarily the same; capital positions range from complete ownerships to servicing 80 percent debt; and the size and type of operation are not only different, but also dynamic in nature. The double-infinite set of conditions violates the typical economic assumption of homogeneity. Moreover, the cost, time, and difficulty of data collection typically precludes enough category separation to achieve tight confidence intervals and variance minimization.

In short, because every ranch is biophysically unique, no single "recipe" of management can be applied everywhere. How the basic principles of good management should be applied can be answered only on a case-by-case basis. It follows that the economic rationality of management decisions can only be evaluated ranch by ranch as well, where it unavoidably intersects with the social and economic variability of the ranchers themselves. It is worth noting that the variability emphasized by Fowler and Gray was not in ranchers' motivations and values-the social factors most often studied to date-but in their economic circumstances.

It is no coincidence that in the conclusion of their seminal paper, Smith and Martin (1972) also recognized the complexity and context dependency of ranching. "It may be that the impact of ranching on the local economy is to be found more in terms of such dimensions as social stability and community leadership rather than in terms of significant economic benefits." They concluded that the "aggregate methods ... traditionally used by economists" could not capture these interactions. "The authors feel they must take an almost anthropological view of the communities' inhabitants in order to examine the detailed interactions involved."

Paradoxically, however, subsequent researchers have repeatedly cited Martin and Jefferies (1966) and Smith and Martin (1972) and utilized their major concepts, without heeding the methodological conclusion that they reached. Instead, conspicuous consumption and a number of "fundamentalisms" have served as the organizing categories for cluster analysis studies aimed at reconstituting, in modified form, the previously 
Table 1. Comparison of characteristics and applications of quantitative vs. qualitative social science research methods.

\begin{tabular}{|c|c|c|}
\hline $\begin{array}{l}\text { Characteristic or } \\
\text { application }\end{array}$ & Quantitative & Qualitative \\
\hline Sample size or area & Larger & Smaller \\
\hline Sample & Randomized & Not randomized \\
\hline Method & Determined in advance & Can evolve during research \\
\hline Variables & $\begin{array}{l}\text { Limited to those identified } \\
\text { in advance }\end{array}$ & $\begin{array}{l}\text { Can be discovered during } \\
\text { research }\end{array}$ \\
\hline Research tools & $\begin{array}{l}\text { Surveys, questionnaires, } \\
\text { statistics }\end{array}$ & $\begin{array}{c}\text { Interviews, observations, } \\
\text { participation, archives }\end{array}$ \\
\hline Research encounter & Standardized, brief & Open ended, longer \\
\hline Appropriate for & $\begin{array}{l}\text { Testing hypotheses and } \\
\text { models }\end{array}$ & $\begin{array}{l}\text { Discovering variables, } \\
\text { refining hypotheses }\end{array}$ \\
\hline Results are & Replicable, generalizable & $\begin{array}{l}\text { Not necessarily replicable, } \\
\text { difficult to generalize }\end{array}$ \\
\hline Logical underpinnings & Hypothetico-deductive & Inductive \\
\hline
\end{tabular}

mentioned "economic assumption of homogeneity." Using questionnaires with Likert scales, scholars have constructed typologies of ranchers based on attitudes toward nature, family, land, ranching, regulation, the federal government, and profit, regressed against data on ranch and herd size, land base, proximity to urbanized areas, and various individual background characteristics (age, education, income sources and size, generations in ranching, and so on). Bartlett et al (1989) arrived at 4 groups and concluded that "job and asset mobility better differentiated ranchers into groups" than did the profit motive. Coppock and Birkenfeld (1999) identified 5 groups: "ranchers" and "hobbyists," both with and without significant public land permits, and "large-scale operators," who were unique in having significant hired (nonfamily) labor but spanned the entire range of the other defining factors. In light of the follow-up study (Peterson and Coppock 2001), large-scale operators might better be distinguished by wealth (which was not directly examined) than by ranch size. The most recent and comprehensive study produced 8 clusters, 4 each under the general headings of "professionals" and "hobbyists" (Gentner 1999; Gentner and Tanaka 2002).

By design, these studies have shed light on land use conversion and likely rancher responses to potential regulatory and policy changes. They also provide useful starting points for understanding ranchers and ranching communities. The Utah studies highlight the importance of economic and demographic constraints on management innovation. Otherwise, however, it is not clear what relation these clusters have to actual management and therefore to conservation or sustainable use of rangelands.

There is a theoretical error, moreover, embedded in the evolution of this research. Economists use profit as their core conceptual category because its quantitative and universal expression in money allows a huge array of particulars to be abstracted from consideration. But if the profit motive does not explain ranchers' behavior-if indeed it is insignificant compared to other concerns and in some cases consciously repudiated-why should it follow that some other value (or set of values) can simply be substituted for it, with the rest of the economists' theoretical edifice left intact? The cluster analysis studies still seek to model rancher behavior in terms of optimization, albeit for some value or values other than monetary profit. They group ranchers into types, each understood as optimizing some definable value (or set of values) such as family, land, or community. This becomes empirically problematic when ranchers express similar values across various geographic, socioeconomic, or demographic gradients, as in the Texas, California, and Utah studies. It is theoretically problematic because satisficing is not equivalent to optimizing. It is not so much about different "types" of ranchers having different values, but about individual ranchers having multiple values that cannot be reduced to any single common denominator and whose relative importance is not necessarily fixed. Sometimes these values align with one another, sometimes they conflict, and exactly which value predominates in a given decision may depend on contextual factors. Many of these values cannot readily be quantified, moreover, and when we turn from motives and values to management and conservation, this difficulty is compounded by the extreme variability among rangelands. In short, the proper inference is the one the economists themselves made: that ranchers' behavior, including their management, cannot be captured using aggregate methods.

In summary, both empirical and theoretical arguments suggest that quantitative methods are of limited utility in understanding ranch management. Empirically, quantitative studies have not found useful correlations between management practices and a variety of demographic characteristics or between management practices and the values and motives of ranchers. Moreover, what these studies have convincingly shown is that any adequate model of how ranchers make decisions cannot rely solely on the profit motive to link new knowledge and practices to actual management on the ground and that other motives are difficult or impossible to quantify. Theoretically, the methodological individualism underlying quantitative methods-with its assumption that individuals can be aggregated into groups whose behavior can be reduced to discrete motives - conflates optimizing and satisficing behavior and is questionable in light of the extreme natural and social variability of western ranches, especially when the behaviors in question are management decisions and related practices.

\section{Advantages of Qualitative Methods}

How should ranch management be studied if quantitative methods are inappropriate or inadequate? A full review of qualitative methods is beyond the scope of this paper, but 3 general arguments can be made in favor of using qualitative methods to improve our understanding of ranch management.

First, because qualitative methods are more flexible and open ended than quantitative methods, they are capable of discovering unanticipated factors that have eluded previous research (Table 1). To achieve statistical significance, quantitative studies require standardized answers to questions formulated in advance. Respondents must choose from among the proffered answers or weightings; responses that fall outside the range of the survey instrument cannot be interpreted. This means that quantitative research can answer only the questions it chooses to pose, running the risk that other important questions and answers may be overlooked. 
One recent qualitative study suggests that previous research on ranchers' management decisions has overlooked numerous important variables. To gain a greater understanding of why some ranchers adopt innovative management practices, Elizabeth Didier and Mark Brunson (2004) developed a list of innovative ranchers by interviewing "key informants" in the ranching and rangeland extension communities in Utah. Because the resulting sample was both small and nonrandom, statistical analysis was ruled out. This had the advantage, however, of allowing the use of a semistructured, open-ended, and "conversational" approach in subsequent interviews with ranchers. Fifteen such interviews were conducted, at which point "new information was no longer encountered," and the study was stopped.

Didier and Brunson discovered 9 previously unidentified factors that characterize, motivate, or inhibit innovative managers. These factors had been invisible to previous researchers because survey instruments had not been designed to capture them. Studies that gathered data on ranch size, for example, did not discover the importance of spatial pattern-the distribution of private and public landownership types and the contiguity or noncontiguity of a ranch's lands-to management decisions. Notably, 5 of the new factors were political or legal in nature: improving relations with agencies, improving public relations, design of government programs, public lands regulations, and liability. Discovery of "new" factors such as these is a necessary step in improving the design of quantitative studies.

Second, qualitative methods are better suited to understanding how ranchers form and adapt their mental models of rangelands and management. Quantitative analysis almost invariably requires a sample size so large that the research encounter, for practical reasons, must be rapid as well as standardized. More time-consuming methods are practicable only with smaller samples or areas of study (or both), which may rule out statistical analysis of the results (Table 1). It is possible that previous studies have employed rapid research tools over large areas in order to produce quantitative results rather than tailoring their methods to suit the subject under study (Gould and Steiner 2002). Consider the temporal and spatial characteristics of ranchers. Studies indicate that the average tenure in ranching is 25 to 30 years (Rowan and White 1994; Gentner and Tanaka 2002) and that the average tenure on the current ranch is about 20 years (Rowan and White 1994). Keeping the ranch and/or the family in ranching indefinitely is a high value for many ranchers, even in the face of steep opportunity costs. All the values and motivations research and at least 1 ethnographic study (Grigsby 1976) attest to ranchers' strong attachment to particular landscapes and to interpersonal relationships developed in those places. Clearly, the processes generating ranchers' mental models are spatially specific and temporally extended. Quantitative methods that require brief encounters over large areas are unlikely to capture these processes.

Third, recent advances in rangeland ecological theory also point to the need for research with greater temporal depth, for which qualitative methods may be all that is available. Especially in arid and semiarid settings, there is growing evidence that the key factors are long-term (or "slow") variables and that the ecological dynamics of rangelands operate over much longer time frames than previously assumed (McClaran 2003; Gibbens et al, in press). Moreover, the advent of state and transition models (Westoby et al 1989) necessarily entails a historical apprehension of rangeland vegetation change (Sayre 2003). A vast array of potential vegetation states, and transitions among them, remains to be documented and correlated with past human activities and/or natural patterns and events. This will require reconstructing histories of both management and landscapes at scales meaningful to actual managers. The environmental history of most rangelands is not well documented, however, and researchers will have to rely heavily on qualitative methods if only because robust quantitative data are scarce. Ranchers will likely be both a primary source of information and a major audience for this research (Bestelmeyer et al 2002).

Previous researchers have offered observations consistent with these arguments without drawing the methodological conclusion advanced here. In the closing sections of their papers on ranchers in Utah, Coppock and Birkenfeld (1999) and Peterson and Coppock (2001) speculated that changing socioeconomic and political conditions "may make isolated technical issues seem increasingly trivial" for ranchers and that economic and political factors, rather than a lack of technology or information, may be the major constraints on management innovations. Except for those identified by Didier and Brunson (2004), these factors remain to be discovered and incorporated into research. Coppock and his colleagues further suggested that management investments may be episodic or ephemeral in response to socioeconomic circumstances-this historical hypothesis also calls for further research. Finally, they concluded that research and extension need greater "2-way communication" and "mutual learning" with rangeland users. All these ideas point to the need for greater understanding of the social dimensions of ranch management and for methods that engage ranchers in sustained, site-specific ways (Table 1).

\section{Suggestions for Future Research}

An example may help illustrate the potential of qualitative research to improve our understanding of ranch management and indicate directions for further research. The Altar Valley of south-central Arizona has experienced significant historical vegetation change (conversion of grasslands to shrub dominance), and the mental model of ranchers there has been shaped by this history and by previous, mostly unsuccessful attempts to restore grasses by bulldozing shrubs-efforts undertaken more than 25 years ago. The ranchers' long-term, historical perspective strongly conditions their current management decisions (eg, to restore fire). It also makes them skeptical of expensive or "silver bullet" solutions, even if promoted by rangeland scientists or extension agents, because bulldozing not only failed in the long term but also helped drive some neighbors out of business. Finally, history informs their views of larger political issues, such as the contention by some environmentalists that livestock exclusion will "restore" the valley's grasslands. These views are unlikely to correlate with any individual rancher's social or economic characteristics because they are generated and reinforced at the community level by longtime local ranchers passing their experiences on to newer neighbors and the next generation. These dimensions of ranch management were revealed through ethnographic and historical re- 
search in which the ranchers themselves were actively involved (Sayre 2000, 2002).

Judged by the standards of quantitative research, the Altar Valley is an isolated case study: unreplicated, uncontrolled, and anecdotal (Table 1). But these standards are neither the only ones available nor the most relevant for applied conservation (Shrader-Frechette and McCoy 1993). The ranchers' historical claims rise above anecdotes because they can be evaluated against published research, archival sources, and outside interviews, for example. The processes driving both management and vegetation change in the valley (eg, climate, fire policies, beef industry economics, rangeland research, and government regulations) are generally larger in scale, so the findings of this case can be expected to have parallels elsewhere. Qualitative research cannot be expected to yield causal predictions for other sites, but it can identify conditions that appear to make sustainable rangeland uses possible or impossible, likely or unlikely. Once identified, these conditions can then be explored elsewhere and potentially tested using quantitative tools (Table 1).

Several other research priorities emerge from the Altar Valley and the preceding analysis. First, we need a better understanding of the range of variation in management practices and outcomes when examined at different locations and scales. What difference has management made or not made to today's rangelands? One way to begin would be to identify areas that are generally agreed to be in very good or very poor condition and conduct case studies (Shrader-Frechette and McCoy 1993) to understand how they got to be that way. Ideally, studies would be done at several spatial scales (eg, pasture, ranch, and watershed). A location where very good and very poor conditions exist side by side might be best of all. Such research would need historical depth, preferably back to presettlement times. Multiple case studies could be coordinated to illuminate patterns at larger scales.

Second, we need to recognize what's new and what's not new about the hobbyist/professional distinction (Coppock and Birkenfeld 1999; Gentner 1999). Affluent ranch owners are as old as ranching itself in the United States, and western ranches have always had multiple dimensions of value for their owners: as real estate investments, personal retreats, tax shelters, family legacies, hunting grounds, political identities, and so forth. Part of the mystique of ranching, historically, derived from its apparent lack of rigid social divisions based on wealth (Sayre 2002). As mentioned, there's little evidence that nonranch wealth determines management in any simple fashion. Coppock and Birkenfeld's (1999) 5th cluster, "large-scale operators," was necessary precisely because the decisions of owners of large ranches (large enough to support hired labor) were not explained by profit motive, dependence on agricultural income, or dependence on public lands.

However, today's "hobbyist" and "professional" ranchers are interacting in a number of ways that are new. In some places, they are joining forces to protect their shared landscapes from residential development, combining the resources and connections of outside wealth with the authenticity and symbolic power of multigeneration ranching. In others, hobbyists are purchasing homesites on working ranches, allowing professionals to realize real estate gains without selling out altogether. In still other places, hobbyists are converting ranches into sanctuaries for bison and other native wildlife, seeking not to "blend in" but to distinguish themselves from the local professionals. These interactions highlight the importance of community level processes that cannot be captured by quantitative methods (Table 1).

Third, these new interactions among ranch owners both reflect and respond to dramatic changes in the underlying economics of western rangelands. There is no longer one dominant highest and best use but myriad, overlapping and competing uses: livestock production, residential development, recreation, water and energy extraction, and conservation. Land use changes may be resisted, accommodated, or abetted by ranch owners, whose perceptions and decisions appear to be collectively formed and subject to thresholds or "tipping points" of abrupt change (Liffmann et al 2000). This may explain why quantitative methods have not been more successful in illuminating relationships between urbanization and ranch management decisions. Qualitative methods should be used to explore the tipping point postulated by Liffmann et al (2000) and to identify factors that determine management and land use at particular sites.

Fourth, if the goal is ecological and economic sustainability, we should look to other continents-some with much longer histories of pastoralism-for principles of management and examples of qualitative research. Qualitative methods to understand interactions of humans and rangelands are not novel outside the United States. In settings such as Mongolia and eastern Africa, researchers have identified and described the importance of such factors as flexibility, reciprocity, diversity, and mobility for sustainable rangeland use (Swift et al 1996; Fernandez-Gimenez and Swift 2003). These are topics that few U.S. rangeland scientists have studied in detail but that can and should be explored in the context of western ranching. Researchers working in West African rangelands have integrated qualitative and quantitative methods in compelling fashion (Fairhead and Leach 1996; Turner 1999a, 1999b). Efforts to utilize qualitative methods in rangeland science are also under way in Australia (Ison and Russell 2000).

The foregoing arguments should not be taken as a rejection of quantitative methods per se. Qualitative methods are simply another set of tools whose utility depends on the questions being asked and the evidence available to answer them. Subjects amenable to quantitative analysis should be studied quantitatively, but it appears that ranch management may not be such a subject, at least at this time. Many ranchers and range conservationists have stated that effective management comes down to cooperation among particular people working on particular landscapes, a sentiment echoed in the findings of a national survey conducted for the Natural Resources Conservation Service (NRCS 1995). If so, rangeland students and professionals who are practiced in qualitative methods will be better prepared to contribute to the improvement of management on western rangelands.

\section{Acknowledgments}

I am grateful to the USDA-ARS-Jornada Experimental Range (JER) for supporting the development of this article. My thanks also to Kris Havstad, Jeff Herrick, Maria Fernandez-Gimenez, Mitch McClaran, the science staff of the JER, and 3 anonymous reviewers for helpful comments on earlier versions. 


\section{Literature Cited}

Bartlet, E. T., R. G. Taylor, J. R. McKean, and J. G. Hof. 1989. Motivation of Colorado ranchers with federal grazing allotments. Journal of Range Management 42:454-457.

Bestelmeyer, B. T., J. R. Brown, K. M. Havstad, R. Alexander, G. Chavez, and J. E. HerRICK. 2002. Viewpoint: issues in the development and use of state-andtransition models for rangeland management. Journal of Range Management $56: 114-126$.

Biswas, B., J. R. Lacey, J. P. Workman, and F. H. Siddoway. 1984. Profit maximization as a management goal on Southeastern Montana ranches. Western Journal of Agricultural Economics 9:186-194.

Coppock, D. L., And A. H. Birkenfeld. 1999. Use of livestock and range management practices in Utah. Journal of Range Management 52:7-18.

Didier, E. A., AND M. W. Brunson. 2004. Adoption of range management innovations by Utah ranchers. Journal of Range Management 57:330-336.

Fairhead, J., And M. LeACH. 1996. Misreading the African landscape: Society and ecology in a forest-savanna mosaic. African Studies Series no. 90. Cambridge: Cambridge University Press.

Fernandez-Gimenez, M., and D. M. Swift. 2003. Strategies for sustainable grazing management in the developing world. In: N. Allsopp, A. R. Palmer, S. J. Milton, K. P. Kirkman, G. I. H. Kerley, C. R. Hurt, and C. J. Brown [eds.]. The VIlth International Rangeland Congress; 26 July-1 August 2003; Durban, South Africa. Irene, South Africa: Document Transformation Technologies. p 821-831

Fliegel, F. C. 1993. Diffusion research in rural sociology. Westport, CT: Greenwood Press.

Fowler, J. M., AND J. R. Gray. 1988. Rangeland economics in the arid west. In: B. A. Buchanan, ed. Rangelands. Albuquerque: University of New Mexico Press. p 67-89.

GentNer, B. 1999. Characteristics of public land grazing permittees [master's thesis]. Corvallis: Oregon State University.

Gentner, B. J., AND J. A. TanakA. 2002. Classifying federal public land grazing permittees. Journal of Range Management 55:2-11.

Gibbens, R. P., R. P. McNeely, K. M. Havstad, R. F. Beck, and B. Nolen. In press. Vegetation changes in the Jornada Basin from 1858 to 1998. Journal of Arid Environments.

Gould, W. R., and R. L. Steiner. 2002. Viewpoint: improving range science through the appropriate use of statistics. Journal of Range Management 55:526-529.

GRIGSBY, T. L. 1976. Buckaroo Ranchers: sociocultural factors related to economic performance among range livestock operators of southeastern Oregon [Ph.D. dissertation]. Eugene: University of Oregon.

Hanselka, C. W., A. McGinty, B. S. Rector, R. C. Rowan, and L. D. White. 1990. Grazing and brush management on Texas rangelands: an analysis of management decisions. Texas Agricultural Extension Service, Texas A\&M University.

Harper, W. M., AND C. EASTMAn. 1980. An evaluation of goal hierarchies for small farm operators. American Journal of Agricultural Economics 62:741-747.

HunTSINGER, L., AND P. HopkINSON. 1996. Viewpoint: Sustaining rangeland landscapes: a social and ecological process. Journal of Range Management 49:167-173.

ISON, R. L., AND D. B. RusSELL. 2000. Agricultural extension and rural development: Breaking out of traditions. Cambridge: Cambridge University Press.

Kreuter, U. P., H. E. Amestoy, D. N. UeCKert, And W. A. McGinty. 2001. Adoption of Brush Busters: results of Texas county extension survey. Journal of Range Management 54:630-639.

Liffmann, R. H., L. Huntsinger, and L. C. Forero. 2000. To ranch or not to ranch: home on the urban range? Journal of Range Management 53:362-370.

LyNAM, T., ANd M. StafFoRd SMith. 2003. Monitoring in a complex world: seeking slow variables, a scaled focus and speedier learning. $I n$ : N. Allsopp, A. R.
Palmer, S. J. Milton, K. P. Kirkman, G. I. H. Kerley, C. R. Hurt, and C. J. Brown [eds.]. The VIIth International Rangeland Congress; 26 July-1 August 2003; Durban, South Africa. Irene, South Africa: Document Transformation Technologies. p 617-629.

Martin, W. E., and G. L. Jeffries. 1966. Relating ranch prices and grazing permit values to ranch productivity. Journal of Farm Economics 48:233-242.

McClaran, M. P. 2003. A century of vegetation change on the Santa Rita Experimental Range. In: M. P. McClaran, P. F. Ffolliott, and C. B. Edminster [eds.]. Santa Rita Experimental Range: 100 years (1903 to 2003) of accomplishments and contributions. RMRS-P-30. U.S. Department of Agriculture, Forest Service, Rocky Mountain Research Station, Ogden UT. p 16-33.

NRCS. 1995. Is there a better way? Reinventing the Natural Resources Conservation Service. Washington, DC: Natural Resources Conservation Service.

Peterson, R., and D. L. Coppock. 2001. Economics and demographics constrain investment in Utah private grazing lands. Journal of Range Management 54:106-114.

Rowan, R. C., H. W. Ladewig, and L. D. White. 1994a. Perceptions vs. recommendations: a rangeland decision-making dilemma. Journal of Range Management 47:344-348.

Rowan, R. C., AND L. D. White. 1994. Regional differences among Texas rangeland operators. Journal of Range Management 47:338-343.

Rowan, R. C., L. D. White, AND J. R. Conner. 1994b. Understanding cause/effect relationships in stocking rate change over time. Journal of Range Management 47:349-354.

Rowe, H. I., E. T. Bartlett, and J. L. E. Swanson. 2001. Ranching motivations in 2 Colorado counties. Journal of Range Management 54:314-321.

Sayre, N. F. 2000. Altar Valley Watershed Resource Assessment, Task Three: Investigate and document historic conditions. Arizona Water Protection Fund project no. 97-041. Altar Valley Conservation Alliance, Tucson AZ. 53 p.

SAYRE, N. F. 2002. Ranching, endangered species, and urbanization in the Southwest: Species of capital. Tucson: University of Arizona Press.

SAYRE, N. F. 2003. Recognizing history in range ecology: 100 years of science and management on the Santa Rita Experimental Range. In: M. P. McClaran, P. F. Ffolliott, and C. B. Edminster [eds.]. Santa Rita Experimental Range: 100 years (1903 to 2003) of accomplishments and contributions. RMRS-P-30. U.S. Department of Agriculture, Forest Service, Rocky Mountain Research Station, Ogden UT. p 1-15.

Shrader-Frechette, K. S., and E. D. McCoy. 1993. Method in ecology: Strategies for conservation. Cambridge: Cambridge University Press.

Smith, A. H., and W. E. Martin. 1972. Socioeconomic behavior of cattle ranchers, with implications for rural community development in the West. American Journal of Agricultural Economics 54:217-225.

Swift, D. M., M. B. Coughenour, and M. Atsedu. 1996. Arid and semiarid ecosystems. In: T. R. McClanahan and T. P. Young [eds.]. East African ecosystems and their conservation. New York: Oxford University Press. $p$ 243-272.

TURNER, M. D. 1999a. Merging local and regional analyses of land-use change: the case of livestock in the Sahel. Annals of the Association of American Geographers 89:191-219.

TURneR, M. D. 1999b. Spatial and temporal scaling of grazing impact on the species composition and productivity of Sahelian annual grasslands. Journal of Arid Environments 41:277-297.

Westoby, M. B., B. WalKer, And I. Noy-MeIR. 1989. Opportunistic management for rangelands not at equilibrium. Journal of Range Management 42:266-274.

Young, K. D., and C. R. Shumway. 1991. Cow-calf producers' perceived profit maximization objective: a logit analysis. Southern Journal of Agricultural Economics 23:129-136.

ZEPADA, L. 1994. Simultaneity of technology adoption and productivity. Journal of Agricultural and Resource Economics 19:46-57. 